\title{
Penerapan Pondasi Keluarga Bagi Generasi Penerus
}

\author{
Joko Santoso \\ Sekolah Tinggi Theologia Nazarene Indonesia \\ ps.johnsantoso@gmail.com
}

\begin{abstract}
Today's family members face increasingly difficult situations. Changes in the times have shifted and shot far, which has an impact on the pattern of family life. So that the family must rebuild and rebuild a foundation that can answer the needs of the times and be in line with God's teachings. The family in managing and laying the foundation for future generations must have a solid foundation; Includes the foundation of family understanding, the foundation of family relationship patterns, the foundation of family goals, and the foundation for achieving goals. To find the results of this study using a qualitative approach that is based on the initial step by collecting the required data, then clarification and description are carried out. Meanwhile, the results are obtained through creating concepts that reveal one's personality and views of the future.
\end{abstract}

Keywords: foundation; family; application

\begin{abstract}
Abstrak
Membina keluarga dizaman sekarang ini menghadapi situasi yang semakin sulit. Perubahan zaman telah bergeser dan melesat jauh, yang berdampak pada pola kehidupan dalam berkeluarga. Sehingga keluarga harus merekonstruksi ulang dan membangun kembali pondasi yang dapat menjawab kebutuhan zaman dan sejalan dengan ajaran Tuhan. Keluarga dalam pengelolaan dan menanamkan pondasi bagi generasi penerus harus memiliki dasar yang kokoh; meliputi pondasi pemahaman keluarga, pondasi pola hubungan keluarga, pondasi tujuan keluarga, dan pondasi pencapaian tujuan. Untuk menemukan hasil penelitian ini menggunakan pendekatan kualitatif yang didasarkan pada langkah awal dengan mengumpulkan data-data yang dibutuhkan, kemudian dilakukan klarifikasi dan deskripsi. Sedangkan hasilnya didapatkan melalui membuat isntrumen konsep-konsep yang menyingkapkan kepribadian diri, menggali potensi dan pandangan terhadap masa depan.
\end{abstract}

Kata Kunci: pondasi; keluarga; penerapan 


\section{Pendahuluan}

Kenyataan hidup di zaman sekarang ini menjadi tantangan semakin besar di dalam keluarga Kristen. Karena selain pergumulan untuk menjaga keutuhan dan keintiman, keluarga Kristen juga menghadapi tantangan untuk tetap menjaga nilai-nilai kebenaran Firman Tuhan di tengah perubahan budaya dan gaya hidup modern saat ini. Kuatnya arus perubahan budaya dan gaya hidup ini tanpa terasa mulai mengguncang nilai-nilai dan tujuan keluarga yang ditetapkan Allah pada mulanya. Peningkatan angka perceraian berujung pada meningkatnya jumlah orang tua tunggal,berdampak pada generasi penerus (anak-anak). Hilangnya figur ayah atau ibu pada anak yang dibesarkan oleh orang tua tunggal sangat mempengaruhi perkembangan kepribadian dan psikologis anak.Hal ini menjadi ancaman serius terhadap iman Kristen, terutama pada keluarga-keluarga Kristen. Menyingkapi kondisi dan situasi seperti ini keluarga sebagai lingkungan utama bagi seluruh anggota keluarga sedini mungkin meletakkan dasar bagi pengelolaan rumah tangga dalam mencapai tujuan dimasa depan.

Yethie dan Nofedin dalam bukunya PAK dan Budi Pekerti, bahwa keluarga merupakan lembaga yang utama dalam pengembangan kepribadian anak-anak dengan bertanggung jawab sepenuhnya memperhatikan dan memenuhi kebutuhan dalam perkembangan jiwa sesuai pertumbuhan usianya. ${ }^{1}$ Pernyataan tersebut mengisyaratkan keluarga mempunyai tugas dan tanggung jawab penuh atas pengelolaan, pembinaan, dan pengembangan anggota keluarga dalam mengajarkan nilai-nilai kehidupan; mental, moral, spiritual, dan karakter dalam pembentukan kepribadian anak-anak. Pengembangan kepribadian secara informal dalam keluarga memiliki peran penting dalam proses pembentukan karakter setiap individu dalam keluarga. ${ }^{2}$ Selanjutnya, Chairinniza Graha ${ }^{3}$ dalam bukunya menjelaskan tiga alasan mengapa orang tua bertanggung jawab dalam melaksanakan pendidikan anak. Pertama, anak adalah anugerah yang diberikan Allah kepada orang tua. Kedua, anak mendapatkan pendidikan pertama kali dari orang tua. Ketiga, orang tua adalah yang paling mengetahui karakter anaknya.

Kehidupan dalam berkeluarga di era digital membutuhkan penangan dan pendekatan yang sangat berbeda. Perkembangan zaman, kemajuan ilmu dan teknologi menuntut pemahaman metode dan strategi yang dapat memberi jawaban sesuai dengan kebutuhan zaman. Perubahan zaman yang dimaksudkan adalah adanya pergeseranpergeseran atau perubahan-perubahan dari apa yang terjadi pada zaman/masa dahulu dengan apa yang terjadi pada masa sekarang ini. Terutama menyangkut perubahan yang terjadi dalam masyarakat. Perubahan seperti ini memang lebih sering dikenal sebagai perubahan sosial. ${ }^{4}$ Untuk mencapai hal tersebut, keluarga harus membuat rumusan dan pola yang sehat, ideal dan tepat. Dengan demikian, akan dapat berfungsi dan berperan aktif dalam membangun relasi dan interaksi yang sehat terhadap seluruh anggota keluarga, menegakkan pola perilaku secara benar, tepat, sesuai dengan kebutuhan zaman dan dengan penuh tanggung jawab.

Keluarga dapat membangun prinsip-prinsip sebagaimana yang diajarkan Alkitab tentang bagaimana menyiapkan dan membangun masa depan keluarga di masa yang akan

${ }^{1}$ Tim Pengembang Ilmu Pendidikan. Ilmu dan Aplikasi Pendidikan Bagian III FIP-UPI, Pendidikan Disiplin Ilmu (Bandung: PT Imperial Bhakti Utama, 2011).

${ }^{2}$ Amirulloh Syarbini, Model Pendidikan Karakter Dalam Keluarga (Jakarta: PT Gramedia, 2014).

${ }^{3}$ Chairinniza, Keberhasilan Anak Di Tangan Orang Tua: Panduan Bagi Orang Tua Untuk Memahami Perannya Dalam Membantu Keberhasilan Pendidikan Anak (Jakarta: PT. Elex Media Komputindo, 2007).

${ }^{4}$ Selvy Iriany Susanti Dupe, “Konsep Diri Remaja Kristen Dalam Menghadapi Perubahan Zaman," Jurnal Ilmiah Religiosity Entity Humanity (JIREH) 2. N0.1 (2020): 53-69. 
datang. Seperti pepatah mengatakan, "Mencegah lebih baik dari pada mengobati." Karena itu, sebelum seseorang masuk dalam kehidupan berkeluarga, pembekalan yang benar tentang hal ini hendaknya diberikan oleh orang yang bertanggung jawab. ${ }^{5}$ Dengan demikian mendidik anak adalah suatu tanggung jawab orang tua yang tidak bisa diwakilkan kepada siapapun juga, ${ }^{6}$ dan dari keluarga inilah segala sesuatu dimulai. Apabila sudah keliru dalam mengawalinya, maka peluang terjadinya berbagai kegagalan pada setiap anggota keluarga sangat mungkin terjadi. ${ }^{7}$ Singgih Gunawan menjelaskan, ada beberapa hal yang menyebabkan orang tua melakukan kekeliruan, yaitu orang tua merasa sudah sudah bekerja keras mencari nafkah dan memenuhi semua kebutuhan anaknya. Apa yang dilakukannya dianggap sudah dikatakan berhasil dalam memenuhi kebutuhan keluarga. Dengan kondisi seperti ini menyebabkan anggota keluarga berjalan sendiri-sendiri. Pandangan seperti ini menyebabkan tidak adanya kesatuan antara ayah dan ibu dan anakanak kehilangan pegangan dan hubungan yang baik. ${ }^{8}$

Seorang suami dan ayah yang baik selalu mendatangkan kebahagiaan atas keluarganya. Ini dibuktikan dengan adanya sikap saling menghargai satu sama yang lain. ${ }^{9}$ Ketahanan keluarga di era modern sekarang ini merupakan sebuah kondisi stabil yang dapat diciptakan oleh sebuah keluarga. Maksudnya, keluarga dalam menjalani kehidupan setiap hari membutuhkan pondasi yang kuat harus terpenuhi. Agar dapat menangkis setiap tekanan hidup dan dapat mengatasi dampak negatif terhadap keluarga. Adapaun aspek dalam ketahanan keluarga tersebut meliputi tiga; yaitu ketahanan fisik, ketahanan sosial, dan ketahanan psikologis. ${ }^{10}$ Penulis berpendapat bahwa dalam membangun keluarga yang sehat dan kuat, maka sebagai orang tua yang menyadari fakta kenyataan yang demikian, segera beranjak untuk merekonstruksi ulang apa yang telah dibangun dan ditanamkan pada diri anak-anak dan membangun pondasi keluarga yang kuat, kokoh dan sejalan dengan ajaran Tuhan.

\section{Metode Penelitian}

Penelitian ini menggunakan pendekatan kualitatif dengan metode studi pustaka, yaitu suatu usaha yang dilakukan oleh peneliti untuk menghimpun informasi yang relevan dengan topik atau masalah yang akan atau sedang diteliti. Informasi itu dapat diperoleh dari buku-buku ilmiah, laporan penelitian, karangan-karangan ilmiah, tesis, dan disertasi, peraturan-peraturan, ketetapan-ketetapan, buku tahunan, ensiklopedia dan sumber-sumber tertulis baik tercetak maupun elektronik lain. ${ }^{11}$ Adapun prosedur yang dilakukan pada penelitian studi pusataka ini meliputi: 1) Menggali ide umum tentang penelitian, 2) Mencari informasi yang mendukungtopik penelitian, 3) mempertegas fokus penelitian dan mengorganisasi bahan yang sesuai, 4) Mencari dan menemukan sumber data berupa sumber pustaka utama yaitu buku dan artikel-artikel jurnal ilmiah, 5) melakukan re-

${ }^{5}$ Kelompok Kerja PAK-PGI, Bertumbuh Dalam Kristus (Jakarta: BPK Gunung Mulia, 2009).

"Mardiharto, "Pola Asuh Pendidikan Kerohanian Pada Anak," PASCA Jurnal Teologi dan

Pendidikan Agama Kristen, Sekolah Tinggi Teologi Babtis Indonesia 15, No.1 (2019): 23-27.

7 Janse Belandina Non Serrano, "Keluarga Sebagai Lembaga Pendidikan Pertama Dan Utama: Studi Kitab Ulangan 6:1-9," REGULA FIDEI Jurnal Pendidikan Agama Kristen 1, No.1 (2016): 72-92.

${ }^{8}$ Riana Udurman Sihombing, Rahel Rati Sarungallo, Peranan Orang Tua Dalam Mendewasakan

Iman Keluarga Kristen Menurut Ulangan 6:6-9, Jurnal KERUSSO, Volume 4 No.1, Hal 35, Maret 2019

${ }_{9}^{9}$ Bungaran Antonius Simanjuntak, Harmonious Family (Jakarta: Yayasan Pustaka Obor Indonesia, 2013), 100.

${ }^{10}$ Herdiana Sihombing et al., "Desain Bahan Pembinaan Suami-Istri Untuk Ketahanan Keluarga Warga Gereja" 1, no. 2 (2020): 110-131.

${ }^{11}$ M. Nazir, Metode Penelitian, (Jakarta: Ghalia Indonesia, 2003), 27. 
organisasi bahan dan catatan simpulan yang didapat dari sumber data, 6) melakukan review atas informasi yang telah dianalisis dan sesuai untuk membahas dan menjawab rumusan masalah penelitian, 7) memperkaya sumber data untuk memperkuat analisis data dan 8) menyusun hasil penelitian.

\section{Hasil dan Pembahasan \\ Pondasi Pemahaman Keluarga}

Pondasi pemahaman keluarga menunjuk pada adanya pengertian yang harus dimiliki oleh seluruh anggota keluarga dalam rangka membangun hidup berumah tangga. Pengertian yang dimaksudkan disini adalah memahami adanya asal mulanya lembaga keluarga tersebut didirikan. Keluarga bermula dari Tuhan yang menciptakan manusia sepasang laki-laki dan perempuan yaitu Adam dan Hawa untuk membentuk sebuah keluarga, sebagai lembaga yang pertama kali dibangun Tuhan di muka bumi ini (Kej. 2:18; Matius 19:1-6). Demikian juga keluarga Kristen didirikan Tuhan di muka bumi ini agar melaksanakan mandat Ilahi dan mempermuliakan nama Tuhan. Maka demi keberlangsungan hidup dan masa depan umat manusia, keluarga mempunyai tugas dan tanggung jawab yang harus dilaksanakan, oleh Adam Hawa dan semua keturunannya dari zaman ke zaman. Selanjutnya secara terus-menerus berjalan disepanjang sejarah manusia yang dapat dilihat dari generasi ke generasi. ${ }^{12}$ Demi terlaksana tujuan tersebut, maka setiap keluarga harus membangun pengertian dan memiliki pemahaman yang benar tentang keluarga, yaitu:

Pertama, keluarga menjadi sangat penting karena pusat kegiatan seluruh anggota keluarga dalam mencapai tujuan. Keluarga menjadi tempat yang tepat untuk pembinaan dan pelatihan dalam mencapai pertumbuhan, membangun prinsip-prinsip hidup, meningkatkan kemampuan diri dan mengembangkan kapasitas. ${ }^{13}$ Selanjutnya setiap anggota keluarga dapat bersinergi memberi perhatian, komitmen, kasih dan menciptakan lingkungan yang kondusif demi terciptanya hubungan, komunikasi dan interaksi yang harmonis dalam meraih harapan.

Kedua, hubungan yang terjadi di dalam keluarga biasanya dilakukan melalui komunikasi dan interaksi antar individu dalam keluarga. Komunikasi dan interaksi dalam keluarga tersebut akan saling mempengaruhi dan memberi dampak satu dengan yang lain dan akan membentuk pola-pola tertentu pada masing-masing individu. Hasil dari interaksi tersebut masing-masing anggota akan memiliki kesan, membangun sikap dan perilaku. Disinilah pola hubungan dalam keluarga terbentuk dan menjadi gaya hidup setiap waktu, sesuai dengan perubahan dan perkembangan yang terjadi.

Ketiga, kesadaran bertanggung jawab dalam pembentukan keluarga harus menjadi ketetapan. Baik bertanggung jawab kepada Tuhan, kepada keluarga dan masyarakat. Setiap anggota keluarga dibangun menjadi pribadi yang bertanggung jawab dalam pembentukan tatanan hidup, keteraturan dan kedamaian keluarga. Oleh karena itu orang tua berkewajiban dan bertanggung jawab atas perkembangan anak-anak sempai menjadi dewasa sebagai titipan Tuhan. ${ }^{14}$ Dalam hubungan antar anggota keluarga menempatkan setiap pribadi harus sesuai dengan kedudukan, posisi dan fungsinya, supaya berjalan dengan baik dan menghasilkan apa yang diharapkan. Meskipun perjalanannya merupakan proses yang

${ }^{12}$ Rinaldus Tanduklangi, "Analisis Teologis Tentang Tujuan Pendidikan Agama Kristen (PAK) Dalam Matius 28:19-20," PEADA-Jurnal Pendidikan Kristen 1, No.1 (2020): 47-58.

${ }^{13}$ Joko Santoso, "Peningkatan Kualitas Diri Dalam Membangun Hubungan Antar Anggota Keluarga," SHIFT KEY Jurnal Teologi dan Pengembangan Pelayanan 8, No 2 (2018): 16-31.

${ }^{14}$ Junita Purba, "Peranan Orang Tua Kristen Dalam Membina Kepribadian Remaja/Pemuda Gereja Pentakosta Indonesia Loroh Tujuh," Jurnal DIDACHE 1, No.2 (2019): 35-48. 
dinamis, namun perlu tetap dijaga kesatuan dan keharmonisan serta rasa tanggung jawab bersama dalam mewujudkannya. Sedangkan pembagian tugas dapat disesuaikan kemampuan, dilaksanakan secara berkala dan bersinergi saling bahu membahu.

Keempat, kebutuhan keluarga untuk mencapai masa depan dan harapan keluarga diperlukan kesadaran dan pemahaman akan pentingnya mengetahui dan memahami kebutuhan yang sesungguhnya diperlukan dan dipenuhi dalam keluarga. Kebutuhan tersebut akan menjadi gudang persediaan dalam memberi kekuatan, kesanggupan dan kemampuan dalam proses menjalani hidup yang panjang dan penuh dinamika. Adapun kebutuhan yang paling fital dibutuhkan dalam membangun hubungan antara anggota keluarga, yaitu: a) Kasih, adalah tali pengikat dalam menjalin hubungan keluarga, sebab di dalam kasih ada pengorbanan, kesediaan diri, dan penerimaan diri. Seberat apapun menjadi tidak berarti dibanding dengan kebersamaan dan kebahagiaan keluarga. Dengan kasih setiap anggota keluarga bisa berbagi untuk saling memberi apa yang dibutuhkan masingmasing. Kunci sejati dalam menciptakan suasana pembinaan yang kondusif dan harmonis adalah kasih, yang menjadikan setiap pribadi individu bagaikan tanah yang subur dalam menerima benih-benih kebenaran Tuhan. ${ }^{15}$ b) Komitmen adalah tali penguat dalam mempertahankan hubungan keluarga. Komitmen pada setiap anggota keluarga menjadikan masing-masing menjaga diri dari penyimpangan terhadap apa yang telah disepakati bersama. Dengan komitmen setiap anggota keluarga dapat saling menghargai, menghormati, menjunjung tinggi apa yang telah disepakati. c) Kesetiaan adalah sebuah sikap dan perilaku yang sangat penting dalam kehidupan sehari-hari. Kesetiaan dapat dilihat dalam kesediaan seseorang membela atau menolong orang lain, mengasihinya dan kesediaannya untuk tidak meninggalkan pihak yang lain. Dengan kesetiaan setiap anggota keluarga dapat bertahan dalam kesukaran, penderitaan dan pergumulan hidup. d) Intregritas adalah konsistensi dan keteguhan yang tidak tergoyahkan dalam menjunjung tinggi nilai-nilai luhur antara tindakan dengan nilai dan prinsip. Integritas menjadi kompas yang mengarahkan sikap perilaku yang merekatkan dalam membangun dan peningkatkan hubungan yang semakin kokoh. Dengan integritas setiap anggota keluarga menjaga diri dalam bersikap dan bertindak.

\section{Pondasi Pola Hubungan Keluarga}

Pada hakikatnya, setiap keluarga sangat memerlukan adanya saling mengasihi, saling menghargai, dan saling memberi, yang menjadi kebutuhan selalu bagi keluarga. Dibutuhkan keahlian dalam berinteraksi sebagai prasyarat dalam membangun keluarga. ${ }^{16}$ Hal ini dilandasi pada prinsip:

Pertama,Tuhan telah menunjukkan pola, gaya hidup dan tujuan untuk keluarga dan menyakinkan bahwa hal itu adalah yang terbaik. ${ }^{17}$ Pola hubungan suami istri terbentuk dalam suatu perkawinan yang sah secara hukum dan dalam konteks kekristenan didasari dengan perjanjian seumur hidup. Pola hidup keluarga sebagai suatu gambaran dalam rumah tangga yang memiliki hubungan yang baik dan harmonis antara suami istri dan anak-anak. ${ }^{18}$ Dalam sebuah keluarga, interaksi antara suami-istri dipengaruhi oleh latar

${ }^{15}$ Bryan Roy dan Antonius Yosef, "Pertumbuhan Rohani Anak Dalam Keluarga Kristen Menurut Efesus 6:4," Jurnal The Way 5, No.1 (2019): 52-69.

16Naomi Sampe, “Komunikasi Interpersonal Keluarga Kristen Memasuki Era 4.0," BIA Jurnal Teologi dan Pendidikan Kristen Kontekstual Vol 2, No. (2019): 72-82.

17Jarot Wijanarko, Menjadi Seorang Suami: Seri Buku Parenting (Jakarta: Keluarga Indonesai Bahagia, 2020).

${ }^{18}$ Ermina Halawa, “Pola Hidup Keluarga Kristen Menurut Kolose 3:18-4:1," Skripsi Sekolah Tinggi Teologi Injili Arastamar (SETIA) (2020). 
belakang kehidupan masing-masing saat masih tinggal dan hidup bersama orang tua masing-masing. Sekalipun kemungkinan adanya kemiripan atau perbedaan, pasti hubungan tersebut membentuk pola baru dalam keluarga yang dibangun.

Bentuk pola yang baru ini memberi landasan dan menentukan pola interaksi di dalam keluarga. Itulah sebabnya pasangan suami istri dalam menjalani hidup bersama harus sepakat secara terus menerus saling membantu, mendukung, dan bekerja bersama untuk mencapai tujuan. Kesepakatan suami istri tersebut dibangun berdasarkan saling menerima kekurangan dan kelebihan, saling pengertian dan mempercayai satu dengan yang lain. Sehingga hubungan timbal balik akan tetap terjaga dengan baik, bahkan semakin dekat, erat dan intim. Disinilah pentingnya pasangan suami istri menciptakan pola yang baru hasil dari kesepakatan dan kesatuan. Supaya dengan pola yang baru ini akan terjalin hubungan timbal balik yang baik, dan menciptakan suatu pola yang tepat dan sesuai dengan kubutuhan didalam keluarga yang dibangun.

Kedua, pola hubungan antara suami dan istri dapat berkembang dengan kehadiran anak-anak. Anak-anak yang dilahirkan di tengah-tengah keluarga ini akan bertambah luas menjadi hubungan antara orang tua dan anak. Hubungan tersebut dapat terbangun dengan baik, biasanya disebabkan dari keberhasilan terjalinnya hubungan yang baik antara suami dan istri. Kemudian secara natural mengalir terhadap pola hubungan dengan anak-anak. Pola hubungan baru yang telah dibangun dan dibentuk oleh suami dan istri dapat diterapkan dalam keluarga terhadap anak-anak yang lahir di tengah-tengah keluarga mereka. Dengan adanya kesesuaian pasangan suami istri, anak hasil buah kasih mereka memiliki gen yang baru. Gen yang diwariskan kepada anak-anak mengandung pola yang telah terbentuk, sehingga anak-anak dapat menyesuaikan dan melaraskan sikap dan tingkah laku mereka seiring dengan terjadinya proses pertumbuhan, perkembangan dan pendewasaan kepribadian dan relasi. Disini orang tua dapat menimpartasikan kualitas interaksi dalam kehidupan keluarga. Akhirnya, hubungan tersebut dapat menghasilkan kehidupan yang diliputi dengan dimensi kehangatan, kenyamanan, keamanan, kepercayaan, ketentraman, dan tanggapan positif dalam situasi dan kondisi apapun juga.

Ketiga, sistem hubungan yang dimiliki keluarga dalam kehidupan sosial harus terbuka tetapi bertanggung jawab dalam setiap perubahan sosial. Keluarga dapat secara bertahap menyesuaikan diri secara tepat dan benar terhadap perubahan-perubahan yang sedang terjadi. Sedangkan proses interaksi satu sama lain berada pada pola yang sudah dibangun agar memberi ruang masing-masing untuk saling berinteraksi. Oleh sebab itu sistem hubungan dalam keluarga perlu aturan-aturan baku sebagai acuan dalam bersikap dan berperilaku yang mengatur sistem komunikasi timbal balik antar anggota keluarga. Karena dengan bertambahnya anggota dalam keluarga muncul banyak reaksi yang bermacam-macam. Akan terjadi dinamika hubungan setiap anggota keluarga semakin mengembang ke arah yang lebih luas. Keluarga harus menjadi tempat untuk saling belajar, berkomunikasi secara efektif, dan belajar bersamai. Berdasarkan hal tersebut, keluarga menjadi wadah belajar bagi seluruh anggota keluarga. ${ }^{19}$

Keluarga sebagai sistem sosial juga tidak terlepas dari konteks sosial dan budaya yang lebih luas di tengah masyarakat pada umumnya. Karena lingkungan masyarakat dimanapun berada, pada umumnya mempunyai ciri khas dan kekuatan untuk mempengaruhi keluarga. Sebagai sistem yang dinamik dan berkembang, maka perubahan dan perbaikan dapat dilakukan oleh keluarga.

${ }^{19}$ Stepanus Turibius Rahmat, Penguatan Peran Keluarga Dalam Pembentukan Karakter Anak, , Surabaya, Mei 2017, Seminar Nasional Dan Konfrensi APD-PAUD Indonesia (Surabaya: FIP Universitas Negeri Surabaya., 2017). 


\section{Pondasi Tujuan Keluarga}

Memilih tujuan keluarga akan berdampak dan menentukan keadaan di masa mendatang. ${ }^{20}$ Setiap orang sudah semestinya memikirkan dan merencanakan bagaimana kehidupannya di masa yang akan datang. ${ }^{21}$ Begitu pula dalam membangun keluarga yang berhasil dan mencapai tujuan. Weinata Sairin \& J.M. Pattiasina menyatakan bahwa tujuan perkawinan adalah membentuk keluarga yang bahagia dan kekal. Untuk itu suami istri perlu saling membantu dan melengkapi agar masing-masing dapat mengembangkan kepribadian dan membantu mencapai kesejahteraan spiriuat dan materiil.22

Pertama, tujuan yang akan dicapai dalam hidup dan keluarganya tersebut merupakan wujud cerminan dirinya. Tidak heran jika banyak yang mengatakan bahwa ketika melihat seorang anak dan menanyakan siapa orang tuanya, jawabannya pantas persis seperti orang tuanya. Anak-anak mempunyai model, karakteristik dan pola hidup yang serupa dengan apa yang diturunkan oleh keluarga orang tuanya. Itulah sebabnya, jika seseorang tidak ingin memiliki keluarga dan mewariskan kehidupan yang buruk dimasa depan, tetapi ingin kehidupan yang lebih baik, maka orang tersebut harus mempunyai tujuan untuk berbuat sesuatu yang lebih baik pula terhadap dirinya sendiri dan keluarganya.

Setiap orang yang hendak membawa hidupnya kepada sesuatu yang ingin dicapai, ditentukan dengan seperti apakah tujuannya dan pondasi yang dibangunnya. Ketika tujuan itu tidak jelas dan tidak berdasar pada pondasi yang pasti dan benar, maka akan menghasilkan kehidupan yang tidak teratur, tidak berbentuk dan tanpa arah yang pasti. Tetapi jika diletakkan pada landasan pondasi yang benar dan tepat, maka akan menetapkan suatu kehidupan yang terarah, teratur dan terstruktur dengan baik, yang membawa kepada peningkatan, pertumbuhan dan kedewasaan.

Disinilah dibutuhkan kemauan, kenyakinan, dan kemantapan dalam mengambil keputusan untuk menetapkan tujuan hidup. Penekanan terhadap penetapan tujuan tersebut bertujuan agar supaya setiap orang dapat menemukan dan menentukan tujuan hidup terhadap dirinya dan anak-cucunya. Pemikiran yang menganggap dan menyatakan bahwa segala sesuatu itu akan terjadi dengan sendirinya dan tidak perlu dirancanakan sangatlah keliru. Seperti yang dipahami oleh orang banyak, yang berpendapat bahwa anak-anak kelak akan menemukan jalan hidupnya dan masa depannya sendiri dimasa depan. Nampaknya pemahaman tersebut masuk akal, tetapi tidak benar, sebab yang membuat anak tahu jalan hidupnya, karena ketika anak itu dalam proses pertumbuhan akan bertemu dengan banyak perkara, masalah dan pengalaman yang membentuk dirinya sehingga menjadi seorang pribadi sebagaimana ia jalani. Kalau demikian berarti anak itu tumbuh dewasa oleh setiap keadaan yang dialami. Keadaan itulah yang menjadikan anak menjadi pribadi sesuai dengan apa yang dialami. Dengan demikian, anak tersebut mendapatkan pendidikan melalui keadaan dan pengalaman yang dialami. Pemahaman tersebut menunjukkan sikap yang sangat tidak terpuji dan tidak bertanggung jawab. Disini orang tua sedang membiarkan anak-anak dalam jalan hidup yang tanpa arah dan tujuan. Sedangkan sepanjang sekian tahun anak-anak tersebut ada dalam lingkungan keluarga menerima proses pendidikan dan pembentukan kepribadian dan pola hidup yang dilakukan orang tua "baik" atau "tidak baik" keadaannya.

${ }^{20} Y u l i a n a$ Demmatande, "Gaya Hidup Kristen Dalam Pengambilan Keputusan Untuk Masa Depan," Jurnal Institute Agama Kristen Negeri Toraja (2020).

${ }^{21}$ Joko Santoso, "Peningkatan Kualitas Diri Dalam Membangun Hubungan Antar Anggota Keluarga" SHIFT KEY Jurnal Teologi dan Pengembangan Pelayanan 8, No 2 (2018): 16-31.

${ }_{22}^{2}$ Weinata Sairin \& J.M. Pattiasina, Pelaksanaan Undang-Undang Perkawinan Dalam Perspektif Kristen (Jakarta: BPK Gunung Mulia, 1996). 
Kedua, visi kehidupan keluarga. Visi adalah melihat klip gambar dari suatu harapan dan rencana dalam hidup keluarga untuk diwujudkan dimasa depan. Visi bukan hanya bicara harapan masa depan, tetapi juga menentukan arah dan tujuan hidup. Supaya oleh visi tersebut hidup menjadi tergambar dengan jelas. Jika seseorang tidak memiliki visi diumpamakan seperti orang buta. Seperti seumpama seorang ayah sedang menuntun anaknya dalam kegelapan. Visi yang didapatkan dari Tuhan akan membawa keluarga menuju arah yang benar dan tepat. Sebab Tuhanlah yang empunya hidup dan masa depan umat manusia. Itulah sebabnya harus dimiliki keluarga, yaitu: a) Visi dalam Tuhan. Visi mengarahkan pandangan tentang masa depan yang berkaitan dengan generasi penerus. Sebagai orang tua yang bertanggung jawab, pasti sudah merancang masa depan yang akan dicapai. Hal ini dibutuhkan visi yang jelas yang bersumber dari Tuhan Sang Pengatur hidup ini dan direncanakan secara matang dan terpola dengan baik. b) Semangat dalam Tuhan. Spirit ini menunjukkan semangat yang diperoleh dari Tuhan yang mendorong dan memotivasi dalam proses pencapaian. Sebagai orang tua yang gigih, pasti memiliki semangat yang tinggi untuk berjuang. Hal ini hanya dapat diperoleh dari Tuhan Sang Sumber kekuatan untuk memampukan melewati setiap rintangan dan tantangan hidup. c) Kekuatan dalam Tuhan. Kekuatan Tuhan membangkitkan sikap sebagai pejuang yang berani menghadapi setiap peperangan dan memenangkan pertandingan. Sebagai orang tua yang tangguh, pasti selalu menunjukkan keperkasaannya dalam setiap waktu dan dalam segala keadaan. Hal ini dapat dimiliki dari Tuhan Sang Penguasa alam semesta yang memberi kekuatan menjangkau harapan dan kemenangan.

\section{Pondasi Masa Depan}

Suami dan istri adalah satu kesatuan yang utuh, yang menjadi sempurna dalam berkarya dan memenuhi panggilan Tuhan. Kesatuan ini adalah kesatuan yang utuh dan sempurna dalam mewujudkan proses pertumbuhan dan pendewasaan mental spiritual seluruh anggota keluarga. Sebab itu orang tua harus menyediakan kebutuhan tersebut, yaitu: pertama, Warisan. Pemikiran yang harus dibangun oleh orang tua adalah tentang apa yang terbaik yang dapat diberikan kepada anak-anak. Sebab seringkali tanpa disadari orang tuatelah berikan kepada anak-anak adalah pemberian yang salah, yaitu: a) Tidak sesuai dengan kebutuhan. b) Tidak tepat waktunya. c) Tidak bermanfaat. Yang seharusnya diberikan orang tua adalah kebutuhan yang sangat mendasar, fital dan dijadikan prioritas utama untuk diusahakan dan diupayakan sampai berhasil. Karena anak-anak berada pada fase-fase yang pasti akan dijalani sesuai dengan proses perkembangan dari lahir sampai bertumbuh menjadi dewasa. Selanjutnya akan melewati fase dimana anak itu akan membangun keluarga. Oleh karena itu, anak-anak perlu sejak dini sudah harus dipersiapkan dengan berbagai praktek nilai-nilai kehidupan dan pengalaman yang diturunkan di dalam keluarga. Beranjak dari pemahaman tersebut, maka orang tua harus memiliki kesadaran diri dalam berperan dan bertanggung jawab sepenuh hati untuk mengimplementasikan nilainilai hidup berdasarkan ketuhanan dan pemahaman iman yang benar sehingga menjadi alat Tuhan dalam membangun keluarga seutuhnya.

Kedua, kasih tanpa syarat. Kasih adalah kebutuhan anak-anak yang sangat mendasar dan vital, yaitu: a) Tuhan itu kasih. Dengan mengajarkan kasih kepada anak berarti memperkenalkan pribadi Tuhan yang limpah dengan belas kasihan dan kemurahan, supaya dengan demikian anak memiliki sifat Tuhan yang dan. b) Ciri Kasih. Kasih yang berasal dari Allah itu mempunyai ciri yang sangat berbeda dengan dunia ini, yaitu: berkualitas tinggi, berkarakter unggul, dan berkekuatan/bernilai kekal. c) Membagi kasih. Harus diperhatikan dengan seksama pada saat membagikan kasih, tidak dapat sampai dengan baik. Pasti ada tembok penghalang yang menghalangi, yaitu: latar belakang orang tua. Orang tua tidak mengalami kasih sayang dimasa lalunya. Sehingga tidak punya pengalaman hidup dalam 
kasih. Akibatnya tidak mempunyai dan menemukan cara yang tepat untuk mengasihi anakanaknya. Sebaliknya, dapat menjadi boomerang atau serangan balik, karna orang tua merasa tidak dihargai atau dihormati. Penerimaan anak. Pemahaman anak tidak sama dengan orang tua. Zamannya sudah berbeda. Jika penerimaan anak secara tidak tepat, akan salah pengertian, dan akibatnya menimbulkan sakit hati, kepahitan dan dendam.

Keempat, tongkat didikan. Didikan adalah bagian yang sangat penting bagi anakanak, sebab tanpa didikan anak-anak akan kehilangan arah. Anak-anak tidak bisa secara tiba-tiba bisa mengetahui, mengerti, memahami, dan melakukan apa saja tanpa diberi pengenalan, pengetahuan dan pengarahan. Alasan yang sangat logis adalah dalam diri anak terdapat warisan orang tua (gen). Warisan orang tua ada yang harus dibuang, ada yang harus diluruskan dan diperbaiki, yaitu warisan tabiat dosa dan sifat yang melekat sejak ada dalam kandungan. Perubahan tidak terjadi dengan sendirinya. Hal ini tidak terjadi dengan sendirinya, tetapi harus ditangani secara rutin, teratur, penuh komitmen dan dedikasi tinggi. Dengan didikan anak akan menerima pelatihan bagaimana cara menjalani kehidupan dengan benar, baik dan tepat. Anak akan terampil ketika menghadapi kesulitan apapun secara terstruktur, terpola dan terencana dengan baik.

Didikan yang dibutuhkan oleh anak-anak adalah: a) Ajaran sehat, yaitu nilai-nilai kebenaran dan norma-norma hidup, dan etika yang sesuai dengan Alkitab. Ajaran atau aturan ini diberikan agar anak akan tahu dengan jelas dan pasti, itu boleh atau tidak, benar atau tidak, berguna atau tidak. Ajaran ini akan menjadi benih yang tumbuh dan hidup dalam diri anak, apabila secara rutin dipelihara dan dirawat dengan baik, dikemudian hari akan menghasilkan buah-buah yang membawa kebahagiaan. b) Keteladanan yang benar. Keteladanan akan memberi bukti nyata apa yang telah diajarkan. Teladan memberi gambaran yang jelas pada diri anak, sehingga terekam dalam pikiran dan hatinya, yang akan diingat selalu. Teladan juga bagaikan air yang terus mengalir memberi kehidupan benih-benih yang telah ditanam. c) Hukuman yang adil. Yang tidak kalah penting adalah hukuman atau tongkat hajaran. Hal ini dlakukan agar anak dapat memahami bahwa setiap kesalahan, kekeliruan atau pelanggaran itu sangat berdampak buruk dan merugikan. Jika secara terus menerus dibiarkan, maka anak akan menjadi terbiasa dengan pelanggaran dan saat menjadi besar anak menjadi orang yang tanpa rasa bersalah melakukan kejahatan. Melakukan hukuman secara adil dan benar, yaitu sesuai dengan takaran kesalahan dan cara yang sesuai dengan pemahamannya. Sehingga saat hukuman tersebut diberikan, diterimanya dengan kesadaran dan kerelaan hati. Berilah hukuman yang mendidik dan bermanfaat pada anak, sehingga anak menerima tidak hanya menaggung ganjaran, tetapi sekaligus memperbaiki kesalahan yg diperbuatnya. d) Memberi Penghargaan. Anak tidak hanya menerima hukuman saat melakukan kesalahan, tetapi anak juga harus menerima penghargaan ketika telah berhasil mencapai hal-hal yang baik dan benar. Hal ini akan menggairahkan dan memberi semangat anak untuk melakukan lebih lagi. Pemberian penghargaan atas prestasi dan hasil yang telah dicapai, akan memberi gambaran, bahwa setiap upaya atau usaha yang dilakukan itu tidak sia-sia, melaikan layak untuk dihargai. Penghargaan yang diberikan bisa berbentuk pujian, hadiah atau diberi kepercayaan yang lebih tinggi. Yang penting tidak berlebihan juga tidak kurang, tetapi sesuai dengan yang telah dilakukannya.

Kelima, mempersiapkan jalan. Orang tua mempersiapkan apa-apa yang diperlukan anak untuk mencapai hari depan yang penuh harapan. Persiapan yang dilakukan sampai menyentuh pada setiap sendi-sendi kehidupan. a) Membuka wawasan tentang masa depan. Hidup adalah suatu perjalanan yang harus dijalani dan tujuan menjadi arah kemana perjalanan akan dituju. Sebab tanpa tujuan yang akan dicapai, maka tidak akan pernah dapat sampai tujuan. Hidup akan menjadi sia-sia jika dibiarkan dan tidak memiliki tujuan yang jelas dan pasti. Maka sebagai orang tua ketika mem-beri wawasan tentang masa depan 
harus selalu mengarah kepada tujuan yang akan dicapai oleh anak. Tujuan tersebut dapat diwujudkan sebagai suatu cita-cita. Disini anak tidak akan menyia-nyiakan waktunya hanya untuk bermain, tetapi memikirkan mau jadi apa kelak nantinya.

b) Menggali potensi yang ada. Saat anak mulai memikirkan masa depan, maka akan mencari cara bagaimana dapat sampai disana. Disini anak diberi pemahaman diri akan kebutuhan kemampuan dan keterampilan. Anak dapat dibimbing untuk mulai menggali dan menemukan potensi apa yang dimilikinya. Dalam menemukan potensi, anak diberikan pengertian yang realistis dan dapat diukur dalam proses secara bertahap. Selanjutnya diberi dukungan belajar lebih baik lagi melalui tranning atau pelatihan-pelatihan skill dan kecerdasan diri. Potensi yang dimiliki merupakan modal besar. Semakin menemukan, semakin mendapat kekuatan yang lebih lagi. Dengan kesungguhan dan ketekunan anak akan dapat membuat perencanaan dan strategi yang tepat, serta mengaktualisasikan potensinya secara baik atau tepat guna. Bahkan, potensi yeng telah diketemukan, memberi gambaran kepadanya, seperti apa yang seharusnya dilakukan. Anak menjadi bijak dan mengambil keputusan-keputusan yang tepat sasaran. c) Kuat dalam kasih karunia Allah. Biasanya orang tua terlalu condong kepada apa yang akan dilakukan oleh anak dalam mengembangkan diri, sehingga lupa bahwa dalam pencapaiannya selalu menjumpai kegagalan demi kegagalan. Tidak semua cita-cita dapat secara mulus dan mudah untuk didapatkan, tetapi dalam prosesnya ada dinamika spirit yang dialami anak. Hal ini dapat membuat anak putus asa dan tidak mau lagi berusaha untuk menjalani. Menyadari kondisi yang demikian, dimana setiap orang mmiliki kemampuan manusiawi yang terbatas, maka sebagai orang tua harus mengarahkan anak memiliki kekuatan spiritual yaitu membutuhkan kasih karunia yang berasal dari Tuhan.

Keenam, memilih pasangan hidup. Meskipun anak sudah bertumbuh menjadi besar dan dewasa, bukan berarti sudah mempunyai pengalaman yang dapat secara sadar dan tepat memilih pasangan hidupnya. Anak membutuhkan pembimbingan orang tua untuk dapat memiliki dengan benar dan sesuai dengan kehendak Allah.a) Pilihan yang sesuai kehendak Tuhan. Pasangan hidup itu adalah sepasang pribadi pria dan wanita yang sepakat untuk hidup bersama selama hidup. Jika sampai tidak jika salah memilih, maka akan mengakibatkan penderitaan selama hidup. Memilih pasangan merupakan bagian terpenting, karena akan menentukan pasangan yang terbaik dan paling tepat. Pilihan yang seperti apa tentunya membuat instrumen daftar kriteria yang memenuhi syarat dalam tinjauan: teologis, spiritual, mental dan latar belakang.b) Mengambil keputusan,Melalui kriteria tersebut diatas, anak dapat mengambil keputusan untuk memilih dan menjalin hubungan dalam pesahabataan. c) Membangun komitmen. Jika dalam perjalanan dilihat ada tanda-tanda yang baik, ada kemajuan yang berarti, dan keseriusan. Bangun komitmen untuk melangkah dalam pertunangan. d). Menikah. Setelah semua langkah-langkah dan proses dijalanan dengan baik, tetapkan sikap untuk menikah.

Berdasarkan tujuan hidup yang harus dimiliki oleh keluarga, harus memiliki pondasi yang kuat, kokoh, dan berbobot. Disertai dengan sikap yang benar, niat yang suci, tekat yang murni dan semangat yang pasti. Sehingga menghasilkan keluarga yang sejahtera dan melahirkan anak-anak yang berkualitas sebagai generasi penerus di masa depan. Ketika orang tua menjalankan fungsinya sebagai orang tua secara maksimal, maka peluang akan ada generasi berikutnya yang lebih berhasil dan lebih baik semakin besar. ${ }^{23}$ Keluarga memiliki peran, fungsi, dan hakekat yang penting jika dilihat dari kacamata kebenaran

23Sally Azaria, Revitalisasi Peran Orang Tua Sebagai Kunci Keberhasilan Generasi Berikutnya, Publikasi Ilmiah Ums (Surakarta, 2015). 
Alkitab. Selanjutnya, keluarga juga menjadi "tangan Allah" untuk merawat serta melanjutkan karya penciptaan Allah penciptaan yang berkelanjutan. ${ }^{24}$

\section{Implikasi}

Kiat dalam menerapkan pondasi dalam keluarga adalah dengan meningkatkan nilai kompetensi diri yang berhubungan dengan diri sendiri; dengan Tuhan, dengan keluarga dan masyarakat; dan dengan keahlian. Hal ini sangatlah penting sebab sangat bermanfaat bagi kehidupannya dan orang-orang yang ada disekitarnya. Dengan meningkatkan kompetensi diri maka keluarga akan dapat mencapai taraf hidup yang lebih baik. Sedangkan kiat dalam meningkatkan kompetensi tersebut dapat dimulai dari orang tua. Yaitu bagaimana orang tua berkemauan keras, berusaha secara terus menerus dan melakukan tahapan demi tahapan sesuai dengan tingkatan yang akan diraih dan hasil yang diinginkan.

Dalam penerapan pelaksanaan pendidikan dalam keluarga, dapat dibuatkan kiat-kiat praktis melalui beberapa aktivasi dan pembuatan langkah-langkah berikut: pertama, sebagai pasangan suami-istri bersatu membangun rumah tangga berdasarkan pada ikatan perjanjian dalam lembaga perkawinan, yang disyahkan oleh Pemerintah. Dalam Undang Undang Perkawinan dinyatakan bahwa suatu perkawinan adalah sah bilamana dilakukan hukum masing-masing agama dan kepercayaannya itu. Di samping itu, perkawinan harus dicatat menurut Peraturan Perundang-undangan yang berlalu. ${ }^{25}$ Ikatan tersebut tidak hanya dinaungi oleh hukum, tetapi lebih pada kekuatan ikatan tersebut dibuat. Tentukan bentuk ikatan yang disepakati bersama, yaitu: a) Memilih bentuk ikatan, adalah pilihan dan keputusan yang diambil oleh masing masing individu. b) Membuat ikatan, sesuai dengan bentuk ikatan yang telah dipilih. c) Mengikatkan diri, pribadi masing-masing dapat mengikatkan ikatan yang telah dibuat dan selanjutnya menyatukan ikatan tersebut menjadi satu ikatan. d) Temuan ikatan berbeda, jika ternyata ditemukan bentuk ikatan yang berbeda, maka pasangan harus menentukan mana yang akan diambil dan menentukan kesepakatan yang baru untuk dijalani.

Kedua, setiap pribadi mempunyai ciri khas yang berbeda satu dengan yang lain. Disinilah terjadi pertemuan dua pribadi yang berbeda dan unik, yang dapat menimbulkan perselisihan dan pertengkaran. Itulah sebabnya suami istri harus berkomitmen untuk membangun kedekatan secara emosional agar memiliki ikatan batin yang kuat dan kokoh. Membangun ikatan batin pasangan suami istri sangatlah penting dan harus dilakukan. Karena ikatan batin akan menghantar pasangan dalam pengenalan pribadi masing-masing semakin dekat. Sehingga terjalin kedekatan, keintiman dan kebahagiaan bersama. Namun untuk membangun ikatan batin tersebut memang tidak mudah, bahkan membutuhkan perjuangan dan pengorbanan dari kedua belah pihak. Tetapi ketika ikatan batin itu telah terbangun dengan baik, justru menciptakan rasa saling membutuhkan satu sama lain dan mempererat keduanya menjadi satu kesatuan yang utuh. Sebagai contoh setiap ungkapanungkapan emosional yang terungkap dipelajari dengan cara mengidentifikasi, menganalisis dan menemukan: a) Apakah itu hanya sesaat. b) Emosi berasal dari luapan hati tapi tidak disadari. c) Akibat dari luka hati yang belum disembuhkan (dari siapapun), d) Emosi yang terungkap itu terjadi pada saat apa, kapan, dan dalam situasi.

Ketiga, setiap orang pasti mempunyai masalah dan kesulitan dalam mengelola dirinya sendiri. Maka pasangan bisa mendukung dan saling membantu agar dapat menemukan dan mengatasi masalah individu masing masing. Cara memberi solusi kepada pasangan

${ }^{24}$ Bakhoh Jadmiko, “Teologi Keluarga: Kajian Terhadap Kejadian1-3 Sebagai Dasar

Pemahaman Esensi Keluarga Kristen," SANCTUME DOMINE Jurnal Teologi 6. No.2 (2018): 83-102.

${ }^{25}$ Weinata Sairin \& J.M. Pattiasina, Pelaksanaan Undang-Undang Perkawinan Dalam Perspektif

Kristen. 
mengatasi problem dirinya. a) Jangan dibiarkan, tetapi carikan cara pasangan untuk dapat keluar dari masalah dengan dirinya sendiri. b) Beri dukungan yang menjadi kebutuhan pasangan bukan menurut kebutuhan diri sendiri, c) Beri dorongan semangat untuk berhasil mengalami kemenangan atas persoalan pribadi pasangan.

Keempat, setiap orang untuk dapat bertumbuh dan menjadi dewasa secara spiritual, psikis/mental dan perilaku butuh sparning parner. Karena orang lain yang lebih mengetahui keberadaan diri seseorang itu benar atau tidak. Disini orang lain selain dirinya yang dibutuhkan kehadirannya dengan tepat dan berpotensi besar adalah pasangannya. Kecuali bagi yang belum menikah, yaitu orang tua dan saudara-saudaranya. Caranya a) Berdikusi tentang ekspetasi diri. b) Berkomitmen untuk maju bersama. c) Bersepakat untuk bersatu dalam mencapai tujuan.

Kelima, bentuk miniatur tujuan keluarga dalam mencapai harapan masa depan. Dengan membuat Family Mission Statement dimana di dalamnya ada statement-statement yang menjadi ciri khas dan pedoman hidup, memberi arah yang jelas, terstruktur dan terukur. a) Mission, keluarga akan menjadi seperti apa. b) Value, nilai-nilai apa yang akan dibangun dalam keluarga. c) Norma, aturan-aturan apa yang hendak ditegakkan menjadi budaya dalam keluarga, d) Ritme, pola efektifitas gerak langkah hidup secara teratur dan berkesinambungan.

Keenam, identifikasi dan analisa kasus, menemukan permasalahan apa yang terjadi di dalam setiap kejadian yang dialami dengan cara: mengidentifikasi, menganalisis dan menemukan apa yang sebenarnya terjadi. Langkah-langkah yang dilakukan yaitu: temukan kasus, faktor penyebab, metode penanganan masalah, penyelesaian masalah, dan kesimpulan. Ketujuh, membuat managemen keluarga, yaitu perencanaan dalam pencapaian tujuan sesuai dengan Family Mision Statement, yaitu yang berkaitan dengan: a) Kehidupan spiritual adalah: pondasi hidup berkeluarga, kerohanian keluarga, nilai/norma hidup keluarga, pelayanan/pengabdian kepada masyarakat.b) Kehidupan psikologis dan mental adalah sistem dalam keluarga, pendidikan, relasi. rekreasi. c) Kehidupan jasmaniah adalah kebutuhan tempat tinggal/sandang dan pangan, pekerjaan dan pengelolaan keuangan

\section{Rekomendasi untuk Penelitian Lanjutan}

Sajian rekomendasi bagi penelitian lanjutan adalah penerapan pondasi keluarga kristen terhadap ketahanan keluarga dalam menghadapi tantangan zaman. Yang dimaksudkan adalah keluarga kristen di zaman sekarang ini menghadapi tantangan yang berat. Antara lain, meningkatnya problematika keluarga dan angka perceraian, degradasi moral yang semakin merosot, dan gaya hidup modern yang meniadakan relasi, kasih sayang, dan kepedulian.

\section{Kesimpulan}

Penerapan pondasi keluarga untuk menjadikan anak-anak sebagai generasi mulia secara turun-temurun, merupakan tanggung jawab bagi para orang tua. Orang tua dengan secara sadar dan usaha sungguh-sungguh harus meletakkan dasar pondasi keluarga yang benar sesuai dengan ajaran Tuhan, dengan memberikan pengajaran-pengajaran yang bermanfaat, keterlibatan diri secara langsung, dan keteladanan kepada anak-anank. Supaya anak akan bertumbuh dengan sehat, terarah dan berhasil melewati proses dalam tahapan psikologi dari balita sampai dewasa. Sehingga anak-anak menerima tongkat estafet dan menjadi generasi penerus dimasa depan.

Kepahlawanan orang tua merupakan warisan yang paling ampuh untuk dapat mewujudkan dan berhasil mencapainya yang harus diturunkan kepada anak-anak sebagai generasi dimasa depan. Adapun kepahlawanan orang tua terhadap anak dengan penuh kesungguhan melakukan langkah-langkah, yaitu: a) Ketangguhan, orang berjuang untuk 
sukses itu banyak, tetapi berjuang untuk kesuksesan anak-anak sangat jarang. Orang tua berpikir bahwa hal itu akan bisa dengan sendirinya sejalan dengan berjalannya waktu. Jika sejak dari awal tidak diperjuangkan, maka akan kehilangan waktu dan kesempatan sangat berharga. b) Pandangan kedepan, orang tua harus punya gambaran kedepan terhadap masa depan anak anaknya. Artinya, memikirkan apa yang terbaik, yang tepat dan maximal bagi anak-anak. Hal ini dilakukan karena secara inplisit, apa yang dimiliki anak terdapat dari orang tua. Paling tidak, tidak jauh dari yang ada. c) Investasi diri, orang tua harus menanamkan diri atau hidupnya sepenuh bagi anak-anaknya. Uang atau fasilitas hanya sebagian kecil, dan hanya menyentuh di luarnya saja. Tetapi, tatkala orang tua mencurahkan hidupnya dan terjun langsung dalam kehidupan anak-anaknya, ia telah menanam hidupnya di dalam diri anak-anaknya. Dalam pelaksanaannya, lakukan sebijaksana mungkin, yaitu pada waktu, saat, kesempatan yang tepat dan sangat dibutuhkan. Ini akan sangat berdampak besar dalam diri anak, yaitu anak-anak menjadi generasi yang kokoh.

\section{Rujukan}

Azaria, Sally. Revitalisasi Peran Orang Tua Sebagai Kunci Keberhasilan Generasi Berikutnya. Publikasi Ilmiah Ums. Surakarta, 2015.

Bryan Roy dan Antonius Yosef. "Pertumbuhan Rohani Anak Dalam Keluarga Kristen Menurut Efesus 6:4." Jurnal The Way 5, No.1 (2019): 52-69.

Chairinniza. Keberhasilan Anak Di Tangan Orang Tua: Panduan Bagi Orang Tua Untuk Memahami Perannya Dalam Membantu Keberhasilan Pendidikan Anak. Jakarta: PT. Elex Media Komputindo, 2007.

Demmatande, Yuliana. "Gaya Hidup Kristen Dalam Pengambilan Keputusan Untuk Masa Depan." Jurnal Institute Agama Kristen Negeri Toraja (2020).

Dupe, Selvy Iriany Susanti. "Konsep Diri Remaja Kristen Dalam Menghadapi Perubahan Zaman." Jurnal Ilmiah Religiosity Entity Humanity (JIREH) 2. N0.1 (2020): 53-69.

FIP-UPI, Tim Pengembang Ilmu Pendidikan. Ilmu dan Aplikasi Pendidikan Bagian III. Pendidikan Disiplin Ilmu. Bandung: PT Imperial Bhakti Utama, 2011.

Halawa, Ermina. "Pola Hidup Keluarga Kristen Menurut Kolose 3:18-4:1." Skripsi Sekolah Tinggi Teologi Injili Arastamar (SETIA) (2020).

Jadmiko, Bakhoh. "Teologi Keluarga: Kajian Terhadap Kejadian1-3 Sebagai Dasar Pemahaman Esensi Keluarga Kristen." SANCTUME DOMINE Jurnal Teologi 6. No.2 (2018): 83-102.

Janse Belandina Non Serrano. "Keluarga Sebagai Lembaga Pendidikan Pertama Dan Utama: Studi Kitab Ulangan 6:1-9." REGULA FIDEI Jurnal Pendidikan Agama Kristen 1, No.1 (2016): 72-92.

Kelompok Kerja PAK-PGI. Bertumbuh Dalam Kristus. Jakarta: BPK Gunung Mulia, 2009.

Mardiharto. "Pola Asuh Pendidikan Kerohanian Pada Anak." PASCA Jurnal Teologi dan Pendidikan Agama Kristen, Sekolah Tinggi Teologi Babtis Indonesia 15, No.1 (2019): 23-27.

Nazir, M. Metode Penelitian. Jakarta: Ghalia Indonesia, 2003.

Purba, Junita. "Peranan Orang Tua Kristen Dalam Membina Kepribadian Remaja/Pemuda Gereja Pentakosta Indonesia Loroh Tujuh." Jurnal DIDACHE 1, No.2 (2019): 35-48.

Rahmat, Stepanus Turibius. Penguatan Peran Keluarga Dalam Pembentukan Karakter Anak, , Surabaya, Mei 2017. Seminar Nasional Dan Konfrensi APD-PAUD Indonesia. Surabaya: FIP Universitas Negeri Surabaya., 2017.

Sampe, Naomi. "Komunikasi Interpersonal Keluarga Kristen Memasuki Era 4.0." BIA Jurnal Teologi dan Pendidikan Kristen Kontekstual Vol 2, No. (2019): 72-82.

Sairin, Weinata \& J.M. Pattiasina. Pelaksanaan Undang-Undang Perkawinan Dalam Perspektif Kristen. Jakarta: BPK Gunung Mulia, 1996. 
Santoso, Joko. "Peningkatan Kualitas Diri Dalam Membangun Hubungan Antar Anggota Keluarga." SHIFT KEY Jurnal Teologi dan Pengembangan Pelayanan 8, No 2 (2018): 16-31.

Sihombing, Herdiana, Elisamark Sitopu, Herowati Sitorus, Roy Charly HP Sipahutar, and Bintahan M. Harianja. "Desain Bahan Pembinaan Suami-Istri Untuk Ketahanan Keluarga Warga Gereja" 1, no. 2 (2020): 110-131.

Sihombing, Riana Unurman dan Rahel Rati Sarungallo. "Peranan Orang Tua dalam Mendewasakan Iman Keluarga Kristen Menurut Ulangan 6:6-9." Jurnal KERUSSO, 2019: 35 .

Syarbini, Amirulloh. Model Pendidikan Karakter Dalam Keluarga. Jakarta: PT Gramedia, 2014. Tanduklangi, Rinaldus. "Analisis Teologis Tentang Tujuan Pendidikan Agama Kristen (PAK) Dalam Matius 28:19-20,." PEADA-Jurnal Pendidikan Kristen 1, No.1 (2020): 47-58.

Wijanarko, Jarot. Menjadi Seorang Suami: Seri Buku Parenting. Jakarta: Keluarga Indonesia Bahagia, 2020. 